\title{
THE EFFECTS OF SATISFACTION AND LOYALTY ON PROFITS AND GROWTH: PRODUCTS VERSUS SERVICES
}

\author{
Bo Edvardsson \\ Service Research Center \\ Karlstad University \\ SE-651 88 Karlstad Sweden \\ Michael D. Johnson \\ University of Michigan Business School \\ 701 Tappan Street \\ Ann Arbor, MI 48109-1234, USA \\ Anders Gustafsson \\ Service Research Center \\ Karlstad University \\ SE-651 88 Karlstad Sweden \\ Tore Strandvik \\ Center for Relationship Marketing and Service Management \\ Swedish School of Economics and Business Administration \\ Fin 00101 Helsinki, Finland
}

\begin{abstract}
The paper uses data from the Swedish Customer Satisfaction Index together with performance data from competing industries to study the difference in logic in terms of customer satisfaction and loyalty between services and products. We find that for product firms loyalty can have a negative effect on company performance, while for service firms the effect is positive. The implication is that service firms must earn their loyalty but product firms can lower their prices and thus retain their customers.
\end{abstract}




\section{Introduction}

This paper focuses on the similarities and differences between products and services with respect to the effects of satisfaction on firm performance. The differences between products and services have received significant research attention of late. That products outperform services on perceived quality and satisfaction, for example, is well documented (Fornell, 1992; Fornell \& Johnson, 1993; Fornell et al., 1996; Johnson et al., 1999a, b). This difference is attributed to the co-production process that typifies the production and delivery of services. Because service production involves more of the human resources of the firm and customers themselves (Bateson \& Hoffman, 1999; Edvardsson, 1997; Gronroos, 1990), it is more difficult to achieve predictably different quality levels. Products and services also demonstrate systematic differences in the relationship between perceived quality or satisfaction and productivity. Whereas changes in quality or satisfaction and productivity are positively related for more product-oriented firms, the relationship is negative for services (Anderson et al., 1997; Huff et al., 1996). Moreover, the interaction between satisfaction and productivity has a greater impact on financial performance for products (Anderson et al., 1997).

Yet these studies have not examined how well the basic logic of the satisfaction- performance relationship operates in the context of goods versus services. According to this logic, satisfaction affects loyalty and retention, which in turn increases revenues and lowers operating costs to increase profitability (Johnson, 1998; Reichheld, 1996). In support of this argument, research using national satisfaction indices in both Sweden and the US shows that satisfaction has a significant positive impact on market value as well as accounting returns (Anderson et al., 1994; Fornell et al., 1995; Inner \& Larcker, 1996, 1998). But according to the satisfaction-performance logic, much of the effect of satisfaction on profits and sales growth is mediated by increased customer loyalty.

An interesting research question is whether this logic is more appropriate for services than products. As we shall argue, the 
satisfaction-loyalty-performance argument is more straightforward in a service context. One of the primary reasons is that the nature of production is fundamentally different in the two cases. Services are the result of a coproduction process that involves the service firm, their employees and customers themselves and occur at a time and place of the customers' choosing. Because products are typically produced prior to sale, there are greater incentives to push inventories through price incentives. As a result, customers who are 'loyal' to a product should not be as profitable, on average, as customers who are loyal to a service.

We test this argument and related propositions using firm-level data from the Swedish Customer Satisfaction Index (Fornell, 1992) over a 3-year period (1995-97). Our results support the basic argument that the 'satisfaction logic' relating satisfaction to profitability is stronger for services than for products. In the following sections we overview the arguments relating satisfaction to profits and the nature of service versus product production. We then formulate a series of propositions and test them using the Swedish data. We end with a discussion of our findings and their managerial implications.

\section{The satisfaction-loyalty-performance logic}

The logic relating satisfaction and loyalty/retention to performance rests on the impact that satisfaction and loyalty have on different sources of customer-related costs and revenues. Satisfaction is defined here as a customer's overall evaluation of their purchase and consumption experience (Johnson \& Fornell, 1991). Loyalty is a customer's predisposition to repurchase from the same firm again, while retention is whether the customer has actually repurchased from the firm. For purposes of our discussion and empirical study, we focus on loyalty as a proxy for retention. This allows us to use a largescale database to test our predictions.

The logic argues that customer costs tend to be 'front-loaded' or occur early in a firm's relationship with a customer, while profits tend to be 'back-loaded' or accrue only after a customer is loyal for 
some time. Following Reichheld (1996) and Johnson (1998), these sources may be categorized into six factors that affect overall costs, revenues and resulting cash flows:

(1) Acquisition costs. The costs of customer acquisition include incentive programmes, awareness advertising, prospecting costs, and the creation of internal customer accounts and records, all of which occur early in a firm's relationship with a customer. Low acceptance of, or response rates to, tactics designed to sign up new customers create significant expenses before customers generate any revenues.

(2) Base revenues. Over each time period that a customer is satisfied and remains loyal, the firm receives base revenue from that customer. This base revenue is more evenly distributed the more frequent the purchase-consumption-repurchase cycle, such as the monthly rate on a phone bill.

(3) Revenue growth. As customers remain satisfied and loyal, opportunities arise to generate increased revenues. This revenue growth comes from two general sources, the cross-selling of

additional products or services and an increase in purchase volume or account penetration. For example, a satisfied insurance customer may increase the size of existing policies while also adding new policies to cover other insurance or financial needs. (4) operating costs. While revenues should grow, operating costs related to the purchase-consumption-repurchase cycle should decrease. The more a firm gets to know customers, their habits, problems and preferences, the easier and less costly it should be to serve them. This would include knowing what types of problems tend to occur on customers' vehicles, how they like their meals prepared, or when they want their hotel room serviced.

(5) Customer referrals or word-of-mouth. Firms that generate outstanding levels of satisfaction and loyalty generate customer referrals and positive word-of-mouth. The referrals and word-ofmouth, in turn, generate additional sales revenues from friends and family. 
(6) Price premiums. Existing customers tend to pay a price premium compared with newer customers. Satisfied, loyalty customers are more likely to be in a habitual or repeat purchase mode of behavior as opposed to a mercenary, problem-solving mode. As a result, they are less likely to take advantage of price discounts as through a coupon or a bonus for switching to a competitor.

The overall result is a per customer profit stream that increases over time. The more loyal the customer and the longer the customer is retained, the more sales and profits the customer generates. Reichheld (1996) reports such profit streams in a variety of service contexts, including the credit card, automobile insurance, automobile service, industrial distribution, industrial laundry service, advertising and life insurance industries.

Yet this performance logic rests on some key assumptions. First, a firm's customer base must have the opportunity to be loyal. While transient customers may generate positive or negative word-of-mouth, they will not generate direct repeat sales or cross-selling opportunities. Second, the costs of switching from one competitor to another must be low. When there are significant barriers to switching, customers may be hostages in that they are relatively dissatisfied but remain loyal (Johnson, 1998; Jones \& Sasser, 1995). At least conceptually, however, these assumptions do not help us distinguish between products and services. But another assumption is that a high level of customer satisfaction creates loyalty. Put differently, loyalty is earned through high quality and satisfaction rather than being bought by, for example, a price promotion or other switching incentive. Based on the differences between product and service production (described later), we argue that loyalty is more likely to be earned for services and bought for products.

Two other assumptions further suggest that the satisfactionperformance logic is stronger for services. Customer referrals should have a greater impact on performance when the benefits of an offering are more intangible and difficult to communicate in the market-place. As services are inherently more intangible than products, customer 
referrals should make a greater contribution to service performance. Finally, the satisfaction-performance logic depends on the regularity of the purchase-consumption-repurchase cycle. For many services, it is a regular and oft repeated cycle (such as using and paying for phone services, bank services, gas-station services, insurance coverage, and so on). While the same is true for nondurable products (such as food products), this is not the case for major durable products (such as computers and automobiles).

\section{Service versus product production: Loyalty earned versus loyalty bought}

A fundamental difference between services and products is in how they are produced and consumed (Bateson \& Hoffman, 1999; Edvardsson, 1997; Gronroos, 1990). Services are activities that are typically produced in an interactive process in which the customers play an active role for the outcome. Some of these services are produced in interaction with the service company's employees (as with airline and hotel services), while in other cases the customer acts as 'sole producer' of the service (as with telecom services or ATM machines). Services are also produced, delivered, and consumed in time and space where processes overlap and the customer carries out core activities. A service company thus offers the prerequisites for a service, not the services per se (Edvardsson, 1997). By prerequisites for the service we mean the proposed offer; how this is to be realized in the form of

process and resource structure. We view these prerequisites for the service as the end result of the service development process. In order to guarantee service quality, there has to be quality in all parts of the prerequisites for the service. It is the customer outcomes from this process, in the form of quality perceptions and satisfaction, which 'is the service' that drives customer loyalty and subsequent firm performance. Because of this co-production process, a service is only produced on an as needed basis. In this way, services represent an extreme form of 'just in time' production ('just as needed'). In contrast, products are the result of a sorting process that includes 
the separation and accumulation of parts or materials, the allocation of these materials into combinations that meet the needs of production units, and the ultimate production of the product (Johnson et al., 1999b; Reekie \& Savitt, 1982). Importantly, these activities occur 'behind the scenes' from the customers' perspective. What emerges from the process is a heterogeneous supply of product offerings among which customers choose.

An important implication of these different production processes is that products are produced in advance of their purchase and consumption while services are not. For products, this creates opportunities and incentives to create 'loyalty' in more than one way. We distinguish here between loyalty earned and loyalty bought. Loyalty is 'earned' when customers receive high quality and are so satisfied with their purchase and consumption experience that they are inherently predisposed toward a particular firm or brand. Loyalty is 'bought' when customers are likely to buy again only because they receive some effective price discounting in, for example, the form of a coupon, trade promotion, or price deal. For products that are produced and inventoried, sales are generated both from those customers who are predisposed to purchase again (loyalists) and mercenaries that buy more on price (see Jones \& Sasser, 1995). The problem is that while the mercenaries generate short-term sales, they involve lower margins and profits and do not necessarily generate future loyalty (Buzzel et al., 1990). For services that are produced as needed and not inventoried, the incentives to push inventories through a price mechanism and generate 'mercenary sales' should be significantly lower. As a result, loyalty to services should be more profitable.

Naturally, a firm's offering is probably composed of both product and service components. Yet certain industries remain primarily services while others are primarily products. We thus test our predictions using a sample of firms from industries that are commonly classified as products versus services. In the following section we formalize our predictions in the form of a conceptual model and series of propositions. 


\section{Conceptual model and propositions}

Figure 1 depicts the model we use to contrast the effects of satisfaction and loyalty on firm performance. The ultimate endogenous constructs in the model are profits and revenue growth. Our previous discussion of the satisfaction-performance logic suggests that both of these performance measures should increase with satisfaction. The logic also suggests that the impact of satisfaction on performance should be at least partially mediated by customer loyalty.

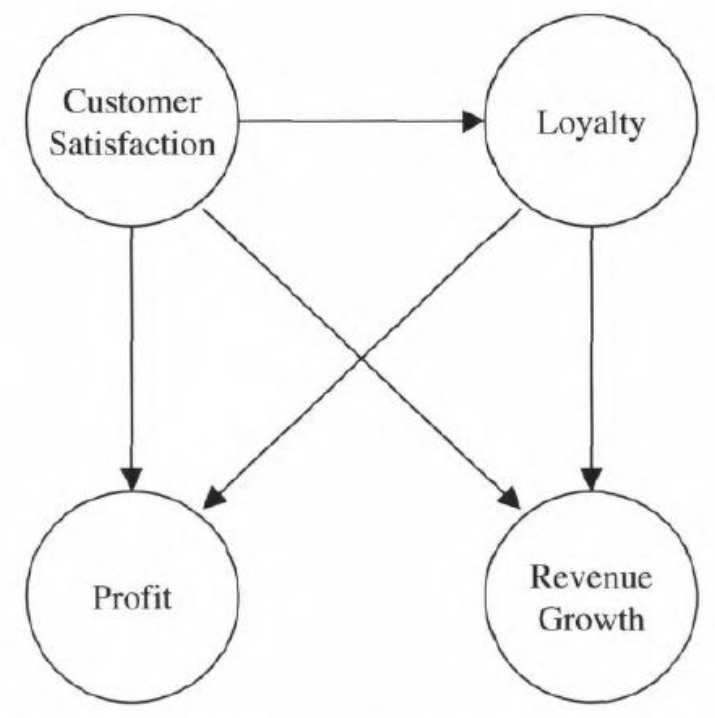

Figure 1. Conceprual model linking satisfaction, loyality and performance.

Accordingly, satisfaction should have a direct effect on profits and growth as well as an indirect effect via loyalty. The direct effect captures those contributions to revenues or cost reductions that are due directly to a positive consumption experience. Consider, for example, that once a product or service is purchased, operating costs decrease only if the customer is satisfied (independent of loyalty per se). Satisfied customers are less likely to demand product repairs or replacements or invoke service guarantees. Positive referrals and word-of-mouth are also a direct function of a positive purchase and consumption experience, not loyalty. The indirect effect of satisfaction via loyalty captures revenue growth and profitability 
due, for example, to repeat purchases, cross-selling and price premiums.

Our discussion suggests systematic differences in model effects for products versus services. We have argued that the satisfactionloyalty-performance logic is more consistent with service production, where loyalty is more likely to be earned, rather than with product production, where the potential to buy loyalty is greater. This suggests that the overall impact of satisfaction on both profits and revenue growth should be greater for services. If our arguments are correct, loyalty should mediate more of the overall effect from satisfaction to firm performance for services. These propositions are stated formally as follows:

- Proposition 1: Customer satisfaction and loyalty have a more positive overall impact on profitability for services than for products.

- Proposition 2: Customer satisfaction and loyalty have a more positive overall impact on revenue growth for services than for products.

- Proposition 3: The degree to which loyalty moderates the positive impact of satisfaction on both profitability and revenue growth is greater for services than for products.

Naturally, there are many other factors that affect profits and revenue growth that are not specified in our model. It will be important, therefore, to focus more on the relative differences between products and services to test our predictions. As described earlier, the positive effect of satisfaction on firm performance is well documented. There are no published studies to our knowledge that test the satisfaction-loyalty-performance logic for products versus services. However, an unpublished paper by Johnson and Hart (1998) examined the effects of satisfaction and loyalty on annualized market returns using a sample of product and service firms from the American Customer Satisfaction Index (ACSI) database. Their results are 
consistent with our predictions and are detailed in our Results section.

Empirical study and results

Two data sources were combined to estimate and contrast the model in Fig. 1 for products and services firms. The satisfaction and loyalty data used in the analysis originate from the Swedish Customer Satisfaction Index (SCSI). The SCSI was established in 1989 and was the first truly national customer satisfaction index for domestically purchased and consumed products and services (for details see Fornell, 1992). It has historically included approximately 130 companies from 32 of Sweden's largest industries. The data are collected through telephone interviews and the number of respondents for each company is 200-250. The financial data in our analysis originate from UC (translated from Swedish as the Information Bureau), which is Sweden's largest and leading business and credit information agency.

The companies and industries in the SCSI are categorized as competitive products, competitive services, or government and public agencies, as shown in Table 1. The classifications are based on standard industrial codes. Our focus is on the competitive product and

Table 1. Industries surveyed in the SCSI

\begin{tabular}{lll}
\hline Competitive products & $\begin{array}{l}\text { Competitive services and } \\
\text { retailers }\end{array}$ & Government and public agencies \\
\hline Automobiles & Airlines & Broadcast TV \\
Food processing & Banks (business) & Pharmacy \\
Newspapers & Banks (public) & Police \\
Personal computers (business) & Clothing retailers & Postal service (business) \\
& Department stores & Postal service (public) \\
& Furniture retailers & Railroad \\
& Gas-service stations & Telecommunications (business) \\
& Grocery stores & Telecommunications (public) \\
& Insurance (business) & Wine and spirits \\
& Insurance (life) & \\
& Insurance (property) & \\
& Mail order companies & \\
& Shipping & \\
& Travel (charter) & \\
\hline
\end{tabular}


service firms. There is generally no financial information available for governmental and public agencies. These agencies also enjoy significant monopoly status in the form of switching barriers when compared with firms in the more competitive industries. Our sample includes 61 cases of competitive product firms and 71 cases of competitive service firms from the SCSI. Each case is a separate company in a given year over the 3 years we have included (1995-97). However, most of the data are from 1995 and 1996. In 1997 the SCSI was forced to reduce the number of companies to half its normal size. This was because Sweden Post, the largest financial supporter and cofounder of the SCSI, could not continue its commitment due to largescale restructuring and cost-cutting activities.

The satisfaction and loyalty constructs in the model are operationalized using the latent variable indices from the SCSI. These two latent variables are built as weighted-averages of multiple questions/indicators included in the SCSI survey (see Fornell, 1992, for details). The reason for working at a latent variable level is that the number of questions related to the areas has varied to some minor extent. The profit latent variable is operationalized for each firm using three reflective measures: reported profits (PI), profits before write-offs (P2) and return on capital employed (P3). Revenue growth is operationalized using a single measure of the total financial turnover for the firm.

Empirical estimation of the model in Fig. 1 was conducted using partial least squares (PLS). PLS estimation accommodates the network of cause and effect relationships in the model and latent variable estimation. PLS is essentially an iterative estimation procedure that integrates principal component analysis with multiple regression. Unlike covariance structure analysis (as via LISREL), the objective of PLS is to explain the ultimate dependent variables in the model (in this case financial performance). PLS is also well suited to small samples and skewed distributions. This motivates the use of PLS for 
estimation of the models represented in Fig. 2 (see Fornell \& Cha, 1994, and Lohmoller, 1989, for detailed descriptions of PLS).

The estimation results are presented in Fig. 2. The results for product firms are to the left and the results for service firms are to the right. The figure includes the path coefficients or impact scores, the measurement loadings for latent variables and the R2 values for
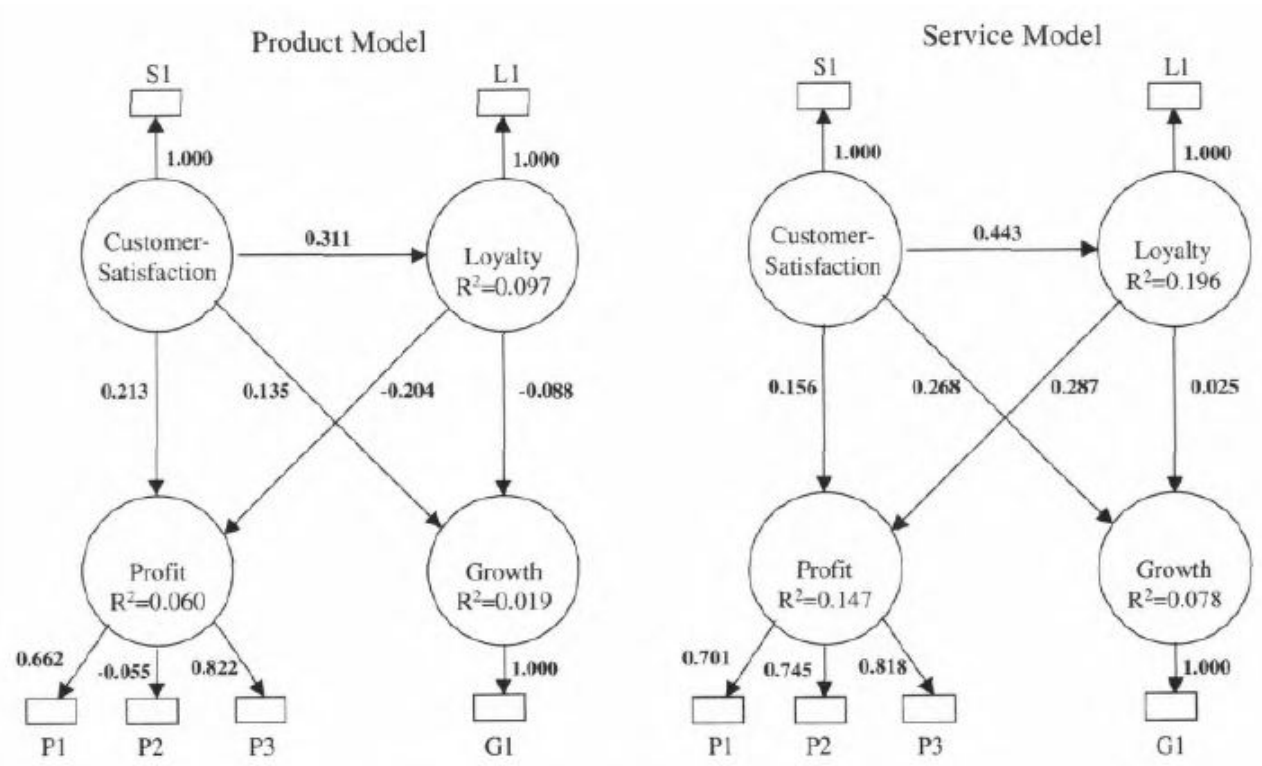

Figure 2. Estimation results for product firms versus service firms.

the endogenous variables (loyalty, profit and growth). Recall that both satisfaction and loyalty constructs are measured using latent variables scores (multiple item indices) from the SCSI, while growth is measured using a single variable. Hence, the measurement loadings in these three cases are all equal to one. Jackknife estimates of the path coefficients show that all impacts are significant (at $p<0.10$ ), with the exception of the impact of loyalty on growth for both models. Notice that while profitability for services is reflected highly in all three measures, profitability for products is a function of profit and return on capital employed (profit before write-offs is not systematically related to the other two profit measures).

Propositions 1 and 2 predict that the overall effect of satisfaction on profit and growth is greater for services than for products. Overall impact is calculated as the sum of the direct impact 
of satisfaction (e.g. 0.156 for the direct impact of satisfaction on profits for the service model) plus the indirect impact of satisfaction via loyalty (e.g. $0.443^{*} \odot .287$ for the indirect impact of satisfaction on profits for the service model). In support of proposition 1, satisfaction has a larger impact on profits for services $(0.213)$ as compared with products $(0.156)$. Likewise, in support of proposition 2, satisfaction has close to two times the total impact on revenue growth for services $(\odot .268)$ compared with products $(0.135)$.

The source of the effect is slightly different for the two performance measures. For profitability, the effect is driven by the significantly positive indirect effect of satisfaction on profits via loyalty for services compared with a negative effect for products. This is a rather stunning finding, that loyalty per se is not profitable for products, and is consistent with the notion that loyalty is more likely to be bought rather than earned. For revenue growth, the difference is driven primarily by the greater direct effect of satisfaction on revenue growth. The overall positive impacts that satisfaction has on the constructs in the model are not surprising in light of previous research using these data. Both the SCSI and the ACSI are significant predictors of loyalty (Fornell, 1992; Fornell et al., 1995) and, as cited earlier, are positively related to both financial and accounting returns. Yet the effect is clearly stronger for services.

Proposition 3 predicts that the larger total impacts for services are due to stronger satisfaction-loyalty-performance links. As noted, this proposition is clearly supported for profits. First, satisfaction has a larger effect on loyalty for services as compared with products $(0.443$ versus $\odot .311)$. Second, the impact of loyalty on profit is positive for services but negative for products ( 0.287 versus -0.204$)$. Both of these findings are consistent with the notion that product loyalty is more likely to be bought while service loyalty' is more likely to be earned. Thus, proposition 3 is clearly supported for profitability. The greater impact on revenue growth for services is, however, due more to the direct effect of satisfaction ( 0.268 for 
services versus 0.135 for products). This finding suggests that revenue growth comes primarily from such factors as customer referrals and word-of-mouth rather than customer loyalty per se.

Overall, our results support clear differences between products and services with respect to how satisfaction drives financial performance. The results are also consistent with the argument that loyalty for hardware can be bought, but services do not go on sale.
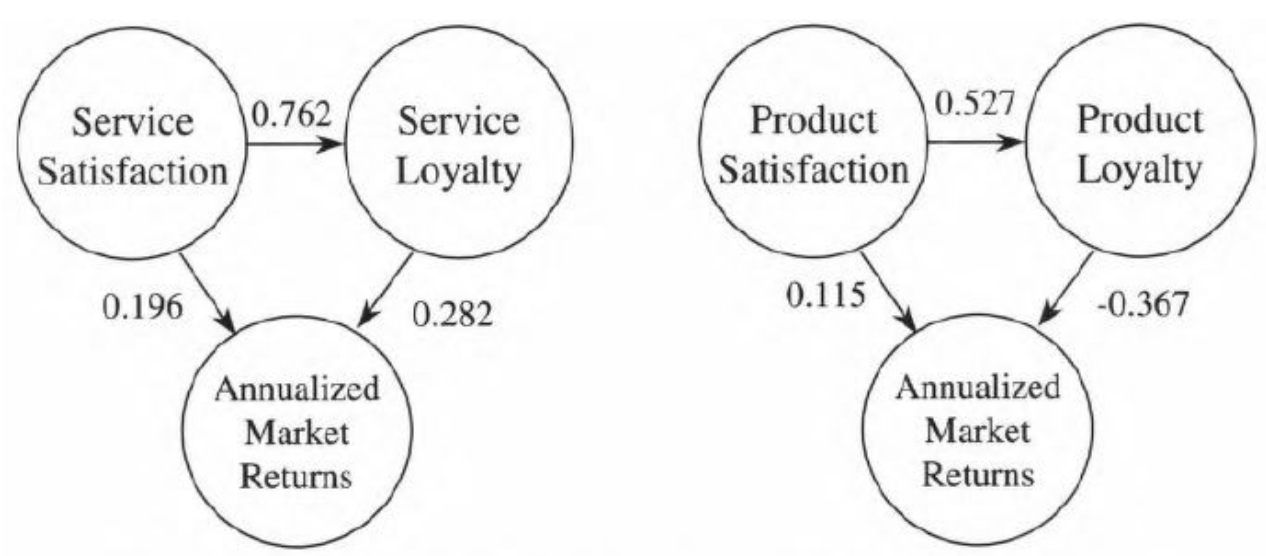

Whereas product

Figure 3. Summary of results for services versus products from fohnson and Hart (1998).

production creates inventories and incentives to move those inventories, services are only produced as needed. Ultimately, our results emphasize the importance of a positive purchase and consumption experience (satisfaction) as opposed to loyalty per se in driving firm performance.

Before moving to our discussion, we report on a similar contrast of product versus service firms by Johnson and Hart (1998) that corroborates our findings. These authors compared 49 service firms to 40 product firms from the ACSI survey whose 10-year annualized market returns are reported in the Fortune 500. In analyzing the Swedish data, we stacked observations from year to year to increase the sample size. In Johnson and Hart's study each firm was a single observation. Rather than stacking the data from year to year, the satisfaction and loyalty scores for 1994 through 1996 were used as multiple measures for satisfaction and loyalty respectively. Likewise, annualized market returns for 1995 and 1996 where used as multiple measures of market returns for each firm. The latent variable impact scores, shown in Fig. 3, are equally as dramatic as those in Fig. 2. (The measurement 
loadings are not shown in Fig. 3, but are all positive and significant.) While both the product and service firms showed a direct effect of satisfaction on market returns, there are three important differences between products and services that are consistent with our results. First, satisfaction has a greater positive impact on loyalty for services. Second, loyalty has a positive effect on profits for services but a negative effect for products. Third, the total effect of satisfaction on returns is much more positive for services $(0.411)$ than for products $(-0.078)$. This difference is even more striking than our results and suggests that the incentives for product firms to buy loyalty are even greater in the US compared with Sweden.

A recent example from the US highlights the phenomenon believed to be at the root of the problem. In 1998 General Motors created a 'Loyalty First' programme which amounted to nothing more than a price incentive to purchase its vehicles. All current GM owners were mailed coupons worth either US\$500 or US\$1000 toward the purchase of another GM vehicle. Within a week, GM dealers began to complain that, while the programme would generate sales, it would erode their profits and do little to generate long-term customer relationships. Indeed, competitors quickly announced that they would be happy to honor the GM coupons.

\section{Discussion and managerial implications}

The results from the study ought to be extremely important for product and service companies alike. As product quality, reliability and durability are getting more and more comparable across competitors (Johnson, 1998), product firms find themselves in the situation of having to distinguish themselves in other ways. Competing on price is a natural but dangerous option that ultimately lowers profitability. In contrast, competing more on services provides a platform for earning loyalty and increasing profitability.

We have argued that there are natural incentives to compete on price for products as opposed to services. A consideration of service quality and how it is communicated is another factor that probably 
creates a disincentive for services to compete on price. What a service company offers is often difficult for customers to assess and understand. Even if the service concept is clear and the prerequisites for a quality service are in place, the intangibility of service results in customers placing great emphasis on the trust they have in a service company. A low price has little or no effect unless the service quality is assured. Rather, a low price or 'extras' are more likely to give negative signals to customers regarding quality. Furthermore, positive word-of-mouth from someone the customer trusts increases the likelihood that the customer will prefer the service. In contrast, it may be much easier to assess product quality prior to purchase (as through test-drives, free samples, objective ratings from government agencies, or concrete warranties).

Both our results and those of Johnson and Hart show that for product firms, loyalty can have negative effects on firm performance. This is perhaps the most important finding from the two studies. It means that companies working with physical products, according to our data, do not make money on loyalty per se. Rather, they make money on customer satisfaction. Customer loyalty, as a behavioral intention, is a strong indicator of how people act in the future and it may very well be the case that customers actually come back to the same company again. What our data indicate, however, is that these customers do not necessarily spend more money with the company when they come back. Rather, they may just be getting a good deal. Satisfaction, on the other hand, cannot be bought in the same way as loyalty. One conclusion is that manufacturing companies should focus on increasing customer satisfaction rather than loyalty to improve their profitability. For services, according to our data, it is inherently difficult for firms to buy loyalty. Rather, they have to earn it.

One natural direction for future research is to explore differences among service firms themselves in terms of how they leverage the satisfaction-loyalty-performance logic. The research could even be extended to include different services offered by the same company where the differences may be even more pronounced. The role of the employees may thus be studied and understood more in- 
depth. However, this requires data at a much lower level of aggregation than those available from the national satisfaction indices.

Another possibility is to compare results from even more European countries within, for example, the ECSI consortium. There is at least one other study that has been carried out along these lines (Johnson et al., 1999b). This study included the three established national satisfaction surveys in Sweden, Germany and the US. The results reveal that across countries, satisfaction is highest for competitive products, lower for competitive services and retailers, and lower still for government and public agencies. Yet the pattern and significance of results vary uniquely by country. The results also support predictably lower levels of satisfaction in Sweden and Germany compared with the US and systematic changes in satisfaction in Sweden over time. Overall, the study supports the use of national indices for making meaningful comparisons of satisfaction on a broad scale. Again, however, richer data are needed to understand the nature of the cultural differences involved and their impact on satisfaction and loyalty.

Finally, it would be interesting to relate results from this type of study to the specific strategies that companies pursue with respect to their emphasis on generating short-run revenues (through costcutting or buying loyalty) as opposed to building long-term customer relationships. 


\section{References}

Andersson, E.W., Fornell, C. \& Lehmann, D.R. (1994) Customer satisfaction, market share, and profitability: findings from Sweden, Journal of Marketing, 58, pp. 53-66.

Andersson, E.W., Fornell, C. \& Rust, R.T. (1997) Customer satisfaction, productivity and profitability: differences between goods and services, Marketing Science, 16, pp. 129-145.

Bateson, J.E.G. \& Hoffman, K.D. (1999) Managing Services Marketing: Text and Reading, 4th Edn (Fort Worth, TX, Dryden Press).

Buzzel, R.D., Quelch, J.A. \& Salmon, W.J. (1990) The costly bargain of trade promotion, Harvard Business Review, Reprint No. 90201.

Edvardsson, B. (1997) Quality in new service development: key concepts and a frame of reference, International Journal of Production Economics, 52, pp. 31-46.

Fornell, C. (1992) A national customer satisfaction barometer: the Swedish experience, Journal of Marketing, 56, pp. 6-21.

Fornell, C. \& Cha, J. (1994) Partial least squares. In: R.P. Bagozzi (Ed.) Advanced Methods of Marketing Research (Cambridge, MA, Blackwell), pp. 52-78.

Fornell, C., Ittner, C.D. \& Larcker, D.F. (1995) Understanding and using the American Customer Satisfaction Index (ACSI): assessing the financial impact of quality initiatives, Proceedings of the Juran Institute's Conference on Managing for Total Quality (Wilton, CT, Juran Institute).

Fornell, C. \& Johnson, M.D. (1993) Differentiation as a basis for explaining customer satisfaction across industries, Journal of Economic Psychology, 14, pp. 681-696.

Fornell, C., Johnson, M.D., Anderson, E.W., Cha, J. \& Bryant, B.E. (1996) The American Customer Satisfaction Index: nature, purpose and findings, Journal of Marketing, 60, pp. 7-18.

Gronroos, C. (1990) Service Management and Marketing: Managing the Moments of Truth in Service Competition (Lexington, Lexington Books ).

Huff, L., Fornell, C. \& Anderson, E.W. (1996) Quality and productivity: contradictory and complementary, Quality Management Journal, 4, pp. 22-39. 
Ittner, C.D. \& Larcker, D.F. (1996) Measuring the impact of quality initiatives on firm financial performance. In: S. Ghosh \& D. Fedor (Eds) Advances in the Management of Organizational Quality, Vol. 1(New York, JAI Press), pp. 1-37.

Ittner, C.D. \& Larcker, D.F. (1998) Are non-financial measures leading indicators of financial performance? An analysis of customer satisfaction, Working Paper, Wharton School, University of Pennsylvania.

Johnson, M.D. (1998) Customer Orientation and Market Action (Upper Saddle River, NJ, Prentice Hall).

Johnson, M.D. \& Fornell, C. (1991) A framework for comparing customer satisfaction across individuals and product categories, Journal of Economic Psychology, 12, pp. 267-286.

Johnson, M.D., Gustafsson, A. \& Cha, J. (1999a) The evolution and future of national customer satisfaction indices, Karlstad, Sweden, Karlstad University, Research Report 98:14.

Johnson, M.D. \& Hart, C. (1998) The essentials of loyalty management, Working Paper, Ann Arbor, University of Michigan Business School.

Johnson, M.D., Herrmann, A.\& Gustafsson, A.(1999b) Customer satisfaction across industries, countries, and time: a test of Alderson's theory of market behavior, Working Paper, Ann Arbor, University of Michigan Business School.

Jones, T.0. \& Sasser, W.E., Jr (1995) Why satisfied customers defect, Harvard Business Review, November- December, pp. 88-99.

Lohmoller, J.-B. (1989) Latent Variable Path Modeling with Partial Least Squares (Heidelberg, Physica).

Reekie, D. \& Savitt, R. (1982) Marketing behavior and entrepreneurship: a synthesis of Alderson and Austrian economics, European Journal of Marketing, 16, pp. 55-66.

Reichheld, F.F. (1996) The loyality effect-The hidden force behind growth, profits and lasting value (Boston, Harvard Business School Press). 